\title{
The Polish language version of the Confusion Assessment Method - a questionnaire for the screening of consciousness disorders
}

\author{
Krzysztof A. Świerzy ${ }^{1}$, Robert Pudlo², Bartosz Wesołowski ${ }^{3}$, Marcin Garbacz ${ }^{4}$, Michał Morawski $^{5}$, \\ Izabela Jaworska ${ }^{4}$, Mariusz Sołtysik ${ }^{1}$, Marian Zembala ${ }^{4}$
}

${ }^{1}$ Department of Psychiatry, Multidisciplinary Hospital, Tarnowskie Gory, Poland

2Department of Psychiatry, School of Medicine with Division of Dentistry in Zabrze, Medical University of Silesia, Katowice, Poland

$3^{3}{ }^{\text {rd }}$ Department of Cardiology, School of Medicine with Division of Dentistry in Zabrze, Medical University of Silesia in Katowice, Silesian Center for Heart Diseases, Zabrze, Poland

${ }^{4}$ Department of Cardiac Surgery and Transplantation, School of Medicine with Division of Dentistry in Zabrze, Medical University of Silesia in Katowice, Silesian Center for Heart Diseases, Zabrze, Poland

${ }^{5}$ Department of Topographic Anatomy, School of Medicine with Division of Dentistry in Zabrze, Medical University of Silesia, Katowice, Poland

Kardiochirurgia i Torakochirurgia Polska 2016; 13 (2): 178-184

\begin{abstract}
Confusion on a somatic basis is a dangerous problem mainly related with aging of the population. Data says that consciousness disorders concern $10-15 \%$ of patients in general wards, and up to $50 \%$ of patients admitted to geriatric wards. The persistence of the symptoms of confusion results in increase of agitation, disorganization, fear, which increases the risk of self-injuries of patients, it causes the need for parenteral feeding and hydratation, as well as maintaining water balance, and also disturbs cooperation, worsening the course and prognosis of the primary disease. It is believed that consciousness disorders are one of the most difficult diagnostic problems and the most difficult therapy problem among psychotic disorders. So far in Poland there have been no screening evaluation tools to assess the occurrence of confusion on the somatic basis. The purpose of this paper is to introduce the Polish translation of the widely used scale to assess consciousness disorders, intended also for middle personnel of health care - Confusion Assessment Method (CAM). Numerous studies over 16 years established the position of CAM as an exceptionally effective standardized diagnostic test, specifying the sensitivity of 94-100\%, specificity from $90-95 \%$, positive predictive value of $91-94 \%$, negative predictive value of $90-100 \%$. The questionnaire and instructions of its interpretation have been translated by doctors with active help from the original creators of CAM. Further studies are required in order to validate and determine the effectiveness of the newly formed diagnostic tool. Key words: symptom questionnaire, screening tests, consciousness disorders.
\end{abstract}

\section{Streszczenie}

Majaczenie na podłożu somatycznym jest powszechnym i niebezpiecznym problemem związanym głównie ze starzeniem się populacji. Podaje się, że zaburzenia świadomości dotyczą 10-15\% pacjentów na oddziałach ogólnych oraz do 50\% pacjentów przyjmowanych w trybie ostrym na oddziały geriatryczne. Utrzymywanie się objawów majaczenia skutkuje narastaniem pobudzenia ruchowego, dezorganizacji, lęku, co zwiększa ryzyko urazów i samookaleczeń pacjentów, powoduje konieczność karmienia i pojenia pozajelitowego oraz prowadzenia bilansu wodnego, a także zaburza współpracę, co pogarsza przebieg i rokowanie choroby podstawowej. Uważa się, że zaburzenia świadomości są jednym z najtrudniejszych problemów diagnostycznych i najtrudniejszym problemem terapeutycznym wśród zaburzeń psychotycznych. Do tej pory w Polsce nie istniały żadne narzędzia do przesiewowej oceny występowania majaczenia na tle somatycznym. Celem niniejszej pracy jest wprowadzenie polskiego tłumaczenia szeroko stosowanej na świecie skali do oceny zaburzeń świadomości, przeznaczonej także dla personelu średniego stużby zdrowia - Confusion Assessment Method (CAM). Liczne badania przeprowadzone w ciągu 16 lat ugruntowały pozycję CAM jako wyjątkowo skutecznego standaryzowanego badania diagnostycznego. Jego czułość określa się na 94-100\%, swoistość - 90-95\%, wartość predykcyjną dodatnią na 91-94\%,wartość predykcyjną ujemną na 90-100\%. Kwestionariusz oraz instrukcje jego interpretacji zostały przetłumaczone przez lekarzy przy czynnej pomocy oryginalnych twórców CAM. Dalsze badania są wymagane w celu walidacji i ustalenia skuteczności nowo powstałego narzędzia diagnostycznego. Słowa kluczowe: kwestionariusz objawowy, zaburzenia świadomości, badania przesiewowe.

Address for correspondence: Krzysztof A. Świerzy MD, Department of Psychiatry, Multidisciplinary Hospital, 17 Wrzosowa St, 42-600 Tarnowskie Gory, Poland, phone: +48 663752 619, e-mail: kafswierzy@gmail.com 


\section{Introduction}

Delirium caused by somatic factors is a widespread and dangerous problem associated with the aging of the population. It has been reported that consciousness disorders are experienced by $10-15 \%$ of patients on general wards and up to $50 \%$ of patients admitted emergently to geriatric wards [1]. The frequent occurrence of delirium stems from the commonness and number of risk factors for this complication, which include, among others: old age, organic injury of the central nervous system, alcoholism, malnutrition, chronic somatic diseases, chronic pain and analgesic treatment, longterm insomnia, electrolyte disorders, blood loss, dehydration, cognitive impairments, depression, metabolic disorders, use of psychoactive agents, immobility, urinary catheterization, and numerous factors associated (directly or indirectly) with surgical procedures [1-4]. One-year mortality of delirium in the population of intensive care unit patients is estimated to be around $40 \%[5,6]$. One should keep in mind that, although qualitative disorders of consciousness are reversible and transient, they directly precede the patient's death in $88 \%$ of cases [7]. Persisting symptoms of delirium result in growing motor agitation, disorganization, and anxiety, which increases the risk of injury or self-harm, necessitates parenteral nutrition and the maintenance of water balance, and impedes cooperation, thus worsening the course and prognosis of the underlying disease [2]. Consciousness disorders are believed to be among the most challenging diagnostic problems and the most difficult therapeutic problem among psychotic disorders [2]. Differential diagnosis typically considers dementia as well as maniacal, paranoid, and delusional syndromes [1]. A particular diagnostic challenge is presented by hypoactive delirium, which is often confused with depression, depressive stupor, catatonia, or apathetic-abulic syndromes [2]. Retrospective studies state that this form of delirium with poor motor activity is observed in the decided majority of cases of delirium in old patients; its frequency correlates with the deterioration of the patient's general condition [7]. These data indicate an obvious need for improving the diagnostics of consciousness disorders on somatic wards, especially those employing surgical procedures. In 1990, a new diagnostic tool for mid-level medical personnel was developed; the purpose of the Confusion Assessment Method (CAM) is the early detection of somatically induced delirium [8]. Numerous studies conducted over the period of 16 years established CAM's position as an effective standardized diagnostic tool; its sensitivity was estimated at 94-100\%, specificity: 90-95\%, positive predictive value: $91-94 \%$, and negative predictive value: $90-100 \%$ [8]. Therefore, the CAM questionnaire had been translated into 10 languages by 2008; it is widely used in Japan, Germany, Finland, Denmark, France, Italy, Spain, Portugal, Turkey, China, and other countries [8].

The aim of this article is to present the Polish version of this screening diagnostic tool.

\section{Material and methods}

The CAM questionnaire consists of 9 points with questions verifying the presence of: acute changes in mental status, attention disorders, disorganized thinking, altered level of consciousness, disorientation, memory impairment, perceptual disturbance, psychomotor agitation or retardation, and sleep-wake cycle disturbances. The questions require the respondent to evaluate the severity and dynamics of the symptoms; space is also provided for descriptive comments. Most questions pertain to information that can be acquired during a single patient examination; answers to the first and last question require information concerning the patient's stay, which can be gathered from the patient's records or the attending medical personnel. The preliminary diagnosis of delirium only requires answers to the first five questions, constituting the so-called short form of CAM. In order to interpret the questionnaire's results, it is necessary to be acquainted with the scoring manual, which has also been translated in this article.

The aim of the authors was to provide a translation that would correspond to the intentions of the questionnaire's original creators to the largest degree possible. Therefore, the original authors were invited to actively cooperate on the project. After receiving approval from Professor Sharon K. Inouye, the director of the Aging Brain Center, the first stage of work on the translation began: two independent translation groups were formed, each consisting of three physicians, including one psychiatrist. The first group translated the original text into Polish, while the second group translated the new Polish text back into English without knowing the original version. The full CAM scale was translated along with the scoring manual. Subsequently, the return translation was sent to the authors of the original questionnaire. Based on their concerns and suggestions, the final version was modified twice before receiving full approval of the original questionnaire's authors. The new Polish version of CAM was accepted for publication among the other official translations on the HELP webpage: (http://www.hospitalelderlifeprogram.org/uploads/disclaimers/CAM_Polish.pdf).

\section{Results}

The Polish version of the questionnaire is presented in Appendage.

\section{Discussion}

This paper introduces the first Polish translation of the American CAM questionnaire. Apart from CAM, other tools for consciousness disorder screening are used around the world, including the Delirium Symptom Interview (DSI) [9], the NEECHAM Confusion Scale [10], the Delirium Observation Screening (DOS) scale [11], the Cognitive Test for Delirium (CTD) [12], and the Descard Tool used in Poland [13] Among these tools, the Confusion Assessment Method is characterized by the highest sensitivity and specificity [14] Evaluation using the CAM questionnaire can be performed by any member of the medical staff based on the instructions contained within the CAM Training Manual. The tool has already been translated into 10 languages and is being used in 10 non-English speaking countries [8]. It can be suspected that introducing the CAM scale into everyday 
practice in Poland will also facilitate the diagnostics of consciousness disorders; however, one should keep in mind that evaluation using a questionnaire is only a screening tool, and one should always strive to confirm its preliminary diagnosis with a clinical examination, preferably conducted by a consulting psychiatrist. The questionnaire has been translated by physicians with active support provided by staff members of the Aging Brain Center, the creators of the original version. The Polish translation still requires validation on somatic wards as well as further studies to determine its effectiveness and sensitivity in clinical conditions.

\section{Conclusions}

The first obtained data indicate that the Polish version of CAM is characterized by good diagnostic accuracy, but its usefulness in everyday practice requires further studies with more precise validation of the questionnaire in clinical conditions.

\section{Disclosure}

Authors report no conflict of interest.

\section{References}

1. Witlox J, Eurelings LS, de Jonghe JF, Kalisvaart KJ, Eikelenboom P, van Gool WA. Delirium in elderly patients and the risk of postdischarge mortality, institionalization, and dementia: a meta-analysis. JAMA 2010; 304: 443-451.

2. Fricchione GL, Nejad SH, Esses JA, Cummings TJ Jr, Querques J, Cassem NH, Murray GB. Postoperative delirium. Am J Psychiatry 2008; 165: 803-812.
3. Krzych LJ, Wybraniec MT, Krupka-Matuszczyk I, Skrzypek M, Bolkowska A, Wilczyński M, Bochenek AA. Complex assessment of the incidence and risk factors of delirium in a large cohort of cardiac surgery patients: a singlecenter 6-year experience. Biomed Res Int 2013; 2013: 835850.

4. Kazmierski J, Kowman M, Banach M, Fendler W, Okonski P, Banys A, Jaszewski R, Rysz J, Mikhailidis DP, Sobow T, Kloszewska I; IPDACS Study. Incidence and predictors of delirium after cardiac surgery: results from The IPDACS Study. J Psychosom Res 2010; 69: 179-185.

5. Kiely DK, Marcantonio ER, Inouye SK, Shaffer ML, Bergmann MA, Yang FM, Fearing MA, Jones RN. Persistent delirium predicts increased mortality. J Am Geriatr Soc 2009; 57: 55-61.

6. Bilikiewicz A. Zespoły psychotyczne z zaburzeniami świadomości niewywotane alkoholem i substancjami psychoaktywnymi. In: Psychiatria kliniczna. Pużyński S, Rybakowski J, Wciórka J (eds.). Elsevier Urban \& Partner, Wrocław 2011; 43-93.

7. Deksnyte A, Aranauskas R, Kasiulevicius V, Sapoka V, Palinauskaite K, Gaidamowicz R. Parametry przedśmiertnego majaczenia. Psychiatr Pol 2014; 48: 145-155.

8. Wei LA, Fearing MA, Sternberg EJ, Inouye SK. The confusion assessment method: a systematic review of current usage. J Am Geriatr Soc 2008; 56: 823-830.

9. Albert MS, Levkoff SE, Reilly C, Liptzin B, Pilgrim D, Cleary PD, Evans D, Rowe JW. The delirium symptom interview: an interview for the detection of delirium symptoms in hospitalized patients. J Geriatr Psychiatry Neurol 1992; 5: 14-21.

10. Neelon VJ, Champagne MT, Carlson JR, Funk SG. The NEECHAM Confusion Scale: construction, validation, and clinical testing. Nurs Res 1996; 45: 324-330.

11. Schuurmans MJ, Shortridge-Baggett LM, Duursma SA. The delirium observation screening scale: a screening instrument for delirium. Res Theory Nurs Pract 2003; 17: 31-50.

12. Hart RP, Levenson JL, Sessler CN, Best AM, Schwartz SM, Rutherford LE. Validation of a cognitive test for delirium in medical ICU patients. Psychosomatics 1996; 37: 533-546.

13. Krzych LJ, Wybraniec MT, Krupka-Matuszczyk I, Skrzypek M, Bochenek AA. Delirium Screening in Cardiac Surgery (DESCARD): a useful tool for nonpsychiatrists. Can J Cardiol 2014; 30: 932-939.

14. Klich-Rączka A, Piotrowicz K, Grodzicki T. Majaczenie w świetle najnowszych zaleceń. Prz Lek 2009; 66: 187-191. 
Appendage. Polish version of the questionnaire

\begin{tabular}{|l|l|}
\hline \multicolumn{1}{|c|}{$\begin{array}{r}\text { KWESTIONARIUSZ CONFUSION ASSESSMENT METHOD (CAM) } \\
\text { OBSERWACJE PRZEPROWADZAJĄCEO WYWIAD }\end{array}$} \\
\multicolumn{1}{|c|}{$\begin{array}{r}\text { Bezpośrednio po zakończeniu badania proszé odpowiedzieć na poniższe pytania. Odpowiedź ma być oparta na obserwacji poczynionej } \\
\text { na podstawie wywiadu oraz testu Mini-Cog. }\end{array}$} \\
\hline $\begin{array}{l}\text { OSTRY POCZĄTEK } \\
\text { 1a. Czy stan psychiczny pacjenta uległ nagłej zmianie w stosunku do stanu normalnego? }\end{array}$ \\
\hline Tak & 1 \\
\hline Nie & 2 \\
\hline Niepewne & 8 \\
\hline 1b. (Jeżeli tak) Opisz charakter zmiany i podaj źródło informacji. & \\
\hline
\end{tabular}

\section{ZABURZENIA UWAGI}

2a. Czy pacjent miał trudności ze skupieniem uwagi, na przykład łatwo się rozpraszał lub z trudem podążał za wypowiedziami rozmówcy? Ani razu w ciągu wywiadu

Przez pewien czas w ciągu wywiadu w tagodnej postaci

Przez pewien czas w ciągu wywiadu w wyraźnej postaci

Niepewne

\begin{tabular}{|l|l|}
\hline & 1 \\
\hline & 3 \\
\hline
\end{tabular}

2b. (Jeżeli obecne) Czy to zachowanie ulegało wahaniom podczas wywiadu, to jest zmieniało swoją intensywność bądź pojawiało się i ustępowało?

\begin{tabular}{|l|l|}
\hline Tak & 1 \\
\hline Nie & 2 \\
\hline Niepewne & 8 \\
\hline Nie dotyczy & 9
\end{tabular}

\section{ZDEZORGANIZOWANE MYŚLENIE}

3a. Czy myślenie pacjenta było zdezorganizowane lub tok myślenia niespójny, to jest czy wypowiedzi były chaotyczne lub niedostosowane, o niejasnym bądź nielogicznym sensie lub pacjent nieprzewidywalnie zmieniał tematy rozmowy?

\begin{tabular}{|l|l|}
\hline Ani razu w ciągu wywiadu & 1 \\
\hline Przez pewien czas w ciągu wywiadu w łagodnej postaci & 2 \\
\hline Przez pewien czas w ciągu wywiadu w wyraźnej postaci & 3 \\
\hline Niepewne & 8
\end{tabular}

3b. (Jeżeli obecne) Czy to zachowanie ulegało wahaniom podczas wywiadu, to jest zmieniało swoją intensywność bądź pojawiało się i ustępowało?

\begin{tabular}{|l|l|}
\hline Tak & 1 \\
\hline Nie & 2 \\
\hline Niepewne & 8 \\
\hline Nie dotyczy & 9 \\
\hline 3c. (Jeżeli obecne) Opisz to zachowanie. & \\
\hline
\end{tabular}

\section{ILOŚCIOWE ZABURZENIA ŚWIADOMOŚCI}

4a. Obejmując całe badanie, jak oceniasz poziom świadomości pacjenta? (PATRZ PYTANIE V Mini-Cog)

\begin{tabular}{|l|l|}
\hline Czuwanie (normalny) & 1 \\
\hline W pogotowiu (nadmiernie czujny, nadwrażliwy na bodźce z otoczenia, niski próg reakcji zaskoczenia) & 2 \\
\hline Senność (usypiający, przebudza się pod wpływem bodźców) & 3 \\
\hline Sopor (reaguje tylko na silne bodźce i ból) & 4 \\
\hline Śpiączka (nie reaguje na żadne bodźce) & 5 \\
\hline Nie do określenia & 8
\end{tabular}

4b. (Jeżeli inne niż czuwanie) Czy ten stan ulegał wahaniom podczas wywiadu, to jest zmieniał swoją intensywność bądź pojawiał się i ustępował?

\begin{tabular}{|l|l|}
\hline Tak & 1 \\
\hline Nie & 2 \\
\hline Niepewne & 8 \\
\hline 4c. (Jeżeli inne niż czuwanie) Opisz to zachowanie. & 9 \\
\hline
\end{tabular}




\section{DEZORIENTACJA}

5a. Czy pacjent był zdezorientowany w jakimkolwiek momencie wywiadu, np. twierdzit, że jest w miejscu innym niż szpital, mylił tóżka lub błędnie podawał porę dnia?

\begin{tabular}{|l|l|}
\hline Ani razu w ciągu wywiadu & 1 \\
\hline Przez pewien czas w ciągu wywiadu w łagodnej postaci & 2 \\
\hline Przez pewien czas w ciągu wywiadu w wyraźnej postaci & 3 \\
\hline Niepewne & 8 \\
\hline
\end{tabular}

5b. (Jeżeli obecne) Czy to zachowanie ulegało wahaniom podczas wywiadu, to jest zmieniało swoją intensywność bądź pojawiało się i ustępowało?

\begin{tabular}{|l|l|}
\hline Tak & 1 \\
\hline Nie & 2 \\
\hline Niepewne & 8 \\
\hline Nie dotyczy & 9 \\
\hline 5c. (Jeżeli obecne) Opisz to zachowanie. & \\
\hline
\end{tabular}

\section{UPOŚLEDZENIE PAMIĘCI}

6a. Czy pacjent miał jakieś problemy z pamięcią, takie jak niemożność odtworzenia zdarzeń podczas pobytu w szpitalu lub trudności z pamiętaniem poleceń?

\begin{tabular}{|l|l|}
\hline Ani razu w ciągu wywiadu & 1
\end{tabular}

\begin{tabular}{|l|l|}
\hline Przez pewien czas w ciągu wywiadu w tagodnej postaci & 2 \\
\hline Przez pewien czas $w$ ciăgu wywiadu w wyraznej postaci
\end{tabular}

\begin{tabular}{|l|l|}
\hline Przez pewien czas w ciągu wywiadu w wyraźnej postaci & 3 \\
\hline
\end{tabular}

\begin{tabular}{|l|l|}
\hline Niepewne & 8 \\
\hline
\end{tabular}

6b. (Jeżeli obecne) Czy to zachowanie ulegało wahaniom podczas wywiadu, to jest zmieniało swoją intensywność bądź pojawiało się i ustępowało?

\begin{tabular}{|l|l|}
\hline Tak & 1 \\
\hline Nie & 2 \\
\hline Niepewne & 8 \\
\hline Nie dotyczy & 9 \\
\hline 6c. (Jeżeli obecne) Opisz to zachowanie. & \\
\hline
\end{tabular}

\section{ZABURZENIA SPOSTRZEGANIA}

7a. Czy u pacjenta występowały zaburzenia postrzegania, tj. omamy, iluzje bądź mylnie interpretował wrażenia zmysłowe, np. twierdząc, że nieruchomy w rzeczywistości przedmiot się porusza?

\begin{tabular}{|l|l|}
\hline Ani razu w ciągu wywiadu & 1 \\
\hline Przez pewien czas w ciągu wywiadu w łagodnej postaci & 2 \\
\hline Przez pewien czas w ciągu wywiadu w wyraźnej postaci & 3 \\
\hline Niepewne & 8 \\
\hline
\end{tabular}

7b. (Jeżeli obecne) Czy to zachowanie ulegało wahaniom podczas wywiadu, tj. zmieniało swoją intensywność bądź pojawiało się i ustępowało?

\begin{tabular}{|l|l|}
\hline Tak & 1 \\
\hline Nie & 2 \\
\hline Niepewne & 8 \\
\hline Nie dotyczy & 9 \\
\hline 7c. (Jeżeli obecne) Opisz to zachowanie. & \\
\hline
\end{tabular}


POBUDZENIE PSYCHORUCHOWE (cz. 1)

8a. Czy w jakimkolwiek momencie badania pacjent wykazywał wzmożoną aktywność ruchową, taką jak niepokój ruchowy, częste nagłe zmiany pozycji, nerwowe poruszanie palcami, wiercenie się na tóżku?

\begin{tabular}{|l|l|}
\hline Ani razu w ciągu wywiadu & 1 \\
\hline Przez pewien czas w ciągu wywiadu w tagodnej postaci & 2 \\
\hline Przez pewien czas w ciągu wywiadu w wyraźnej postaci & 3 \\
\hline Niepewne & 8 \\
\hline
\end{tabular}

8b. (Jeżeli obecne) Czy to zachowanie ulegało wahaniom podczas wywiadu, tj. zmieniało swoją intensywność bądź pojawiało się i ustępowało?

\begin{tabular}{|l|l|}
\hline Tak & 1 \\
\hline Nie & 2 \\
\hline Niepewne & 8 \\
\hline Nie dotyczy & 9 \\
\hline 8c. (Jeżeli obecne) Opisz to zachowanie. & \\
\hline
\end{tabular}

\section{SPOWOLNIENIE PSYCHORUCHOWE (cz. 2)}

8a. Czy w jakimkolwiek momencie badania pacjent wykazywał wyraźnie obniżoną aktywność ruchową, taką jak ospałość, wpatrywanie się stale w jeden punkt, pozostawanie w jednej pozycji przez długi czas lub poruszanie się bardzo powoli?

\begin{tabular}{|l|l}
\hline Ani razu w ciągu wywiadu & 1
\end{tabular}

\begin{tabular}{|l|l|}
\hline Przez pewien czas w ciągu wywiadu w tagodnej postaci & 2 \\
\hline Przez pewwen cza w iagu wywiadu w wyaznej postaci
\end{tabular}

\begin{tabular}{|l|l|}
\hline Przez pewien czas w ciągu wywiadu w wyraźnej postaci & 3
\end{tabular}

\begin{tabular}{|l|l}
\hline Niepewne & 8 \\
\hline 8b. (lezeli obecne) Czy to zachowanie ulegato wahaniom podczas wywiadu, ti. zmienialo swoja i
\end{tabular}

8b. (Jeżeli obecne) Czy to zachowanie ulegało wahaniom podczas wywiadu, tj. zmieniało swoją intensywność bądź pojawiało się i ustępowało?

\begin{tabular}{|l|l|}
\hline Tak & 1 \\
\hline Nie & 2 \\
\hline Niepewne dotyczy & 8 \\
\hline 8c. (Jeżeli obecne) Opisz to zachowanie. & 9 \\
\hline
\end{tabular}

\section{ZABURZENIA RYTMU DOBOWEGO}

9a. Czy są oznaki zaburzeń rytmu dobowego, takie jak nadmierna senność w ciągu dnia z bezsennością w nocy?

\begin{tabular}{|l|l|}
\hline Tak & 1 \\
\hline Nie & 2 \\
\hline Niepewne & 8 \\
\hline 9b. (Jeżeli tak) Opisz to zaburzenie. & \\
\hline
\end{tabular}




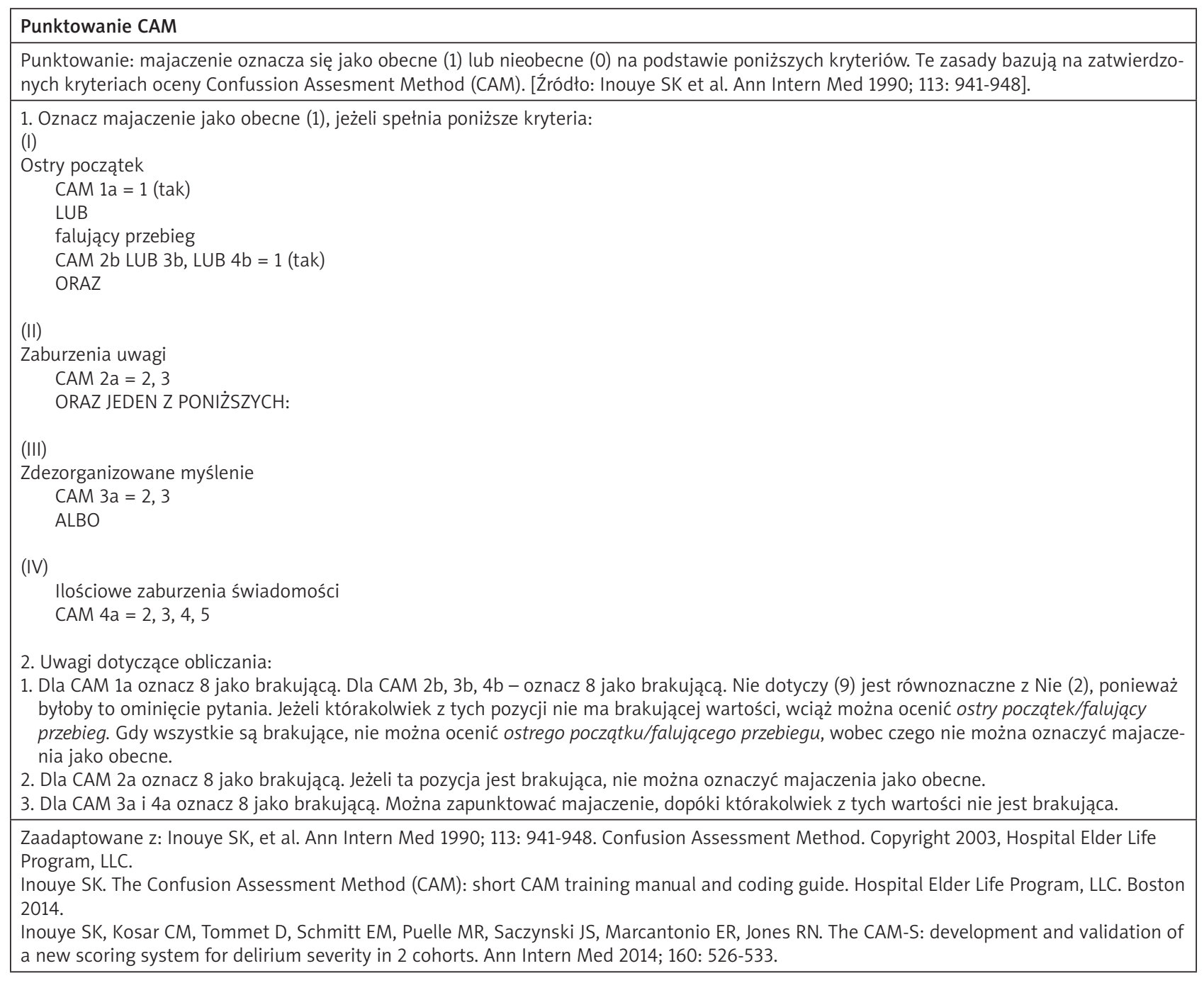

